\title{
Academic patenting: The importance of industry support
}

\author{
Cornelia Lawson
}

\author{
Please cite as: Lawson, C. (2013) Academic patenting: The importance \\ of industry support, Journal of Technology Transfer, 38 (4), 509-535
}

\begin{abstract}
This paper provides evidence that university-industry collaboration is important for turning commercial opportunities into patents. The results suggest that researchers who receive a large share of research grants from industry have a higher propensity to file a patent. Small dissemination grants generally exert a positive effect, whether they come from industry or not. It also finds that these interactions do not increase the number of industry owned patents alone but benefit universities' commercialisation efforts in general.
\end{abstract}

Keywords: Academic patenting; University-industry collaboration; Technology transfer; Sponsored research.

JEL codes: O31, O34, I23

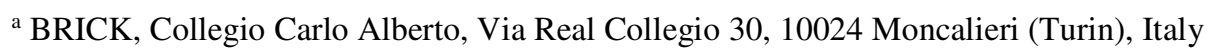

b University of Turin, Department of Economics S. Cognetti de Martiis, Via Po 53, 10124 Turin, Italy

c City University London, Department of Economics, Northampton Square, London, EC1V 0HB, UK

* Correspondance address: University of Turin, Department of Economics S. Cognetti de Martiis, Via Po 53, 10124

Turin, Italy, Email: cornelia.meissner@unito.it, Tel: +39 011670 5095, Fax: +39011 6703895

The author would like to thank Albert Banal-Estanol, Mireia Jofre-Bonet, Alan Marco, Pierre Mohnen, Reinhilde Veugelers and participants of the DIME Final Conference (Maastricht), SEEK Kick-Off Conference (Mannheim), Zvi Griliches Seminar (Barcelona) and EARIE Conference (Stockholm) for their comments and suggestions. She would also like to thank Francesco Lissoni and Valerio Sterzi for sharing data from the EP-INV project. The data for this paper were collected as part of the ESRC research grant RES-000-22-2806. The paper further contributes to the research projects "Policy Incentives for the Creation of Knowledge: Methods and Evidence" (PICK-ME, Grant 266959) and "An Observatorium for Science in Society based in Social Models" (SISOB, Grant 266588), both funded by the European Union D.G. Research. Sponsorship through a Network of Excellence DIME Mobility Fellowship and a Short Visit Grant within the ESF Activity 'Academic Patenting in Europe' as well as support from Collegio Carlo Alberto and CIRCLE Lund University are also gratefully acknowledged. 
Lawson. Academic patenting: The importance of industry support.

Published in The Journal of Technology Transfer

\section{Introduction}

Universities have traditionally been an important source for knowledge creation and economic growth as they support industrial innovation through solving fundamental research problems (e.g. Aghion et al., 2008; Gibbons and Johnston, 1975; Nelson, 1986) and contribute directly through licensing of inventions resulting from their research (e.g. Henderson et al., 1998; Thursby and Kemp, 2002). Since the 1980s universities have become increasingly proactive in their commercialisation efforts and the number of academic staff involved in patenting has increased dramatically (e.g. Jensen and Thursby, 2001; Siegel et al., 2007; Verspagen, 2006).

Numerous studies have investigated the determinants of academic patenting activity and have found several factors that potentially affect a researcher's propensity to patent. Firstly, many papers stress the importance of patenting support provided through the commercialisation unit of the university and through financial incentives in form of royalties (Lach and Schankerman, 2008; Thursby and Kemp, 2002). A second body of literature has focused on the link between scientific and commercial activity of individual researchers by measuring their publications (e.g. Azoulay et al., 2007; Stephan et al. 2007). Some recent papers, especially in the field of organisational behaviour, have further highlighted that the influence of peers or mentors on researcher's attitudes towards commercialisation is one of the main factors for continuous entrepreneurial efforts (Bercovitz and Feldman, 2008; Ozgen and Baron, 2007; Stuart and Ding, 2006).

This paper aims to contribute to the latter stream of patenting literature by empirically investigating the influence of partners from industry on academic patenting. Interviews with engineers conducted by Agrawal and Henderson (2002) suggest that interactions with industry can steer academics towards commercialisation. Further, they can help academics to recognise opportunities for commercialisation (Ozgen and Baron, 2007). This points to the possibility that industry partners influence a researcher's attitude towards patenting as well as their perceived opportunities, resulting in an increase in patenting activity. However, not all industry grants may have the same purpose. Hottenrott and Lawson (2012) show that research motivated by small and medium-sized enterprises has a positive effect on patenting rates while large firms effect patenting negatively. This paper differs between small and large grants, assuming that the latter is 
Lawson. Academic patenting: The importance of industry support.

Published in The Journal of Technology Transfer

designed to support research and produce publications while the first enables dissemination and knowledge transfer. Large grants are mainly provided by public agencies with few large grants coming from industry. However, Thursby et al. (2009) and Verspagen (2006) point at such joint research projects as a source of industry owned patents in a US and European context. Thus, the large sponsoring contracts with industry may indeed increase patenting opportunities for researchers. Small grants on the other hand are an indicator of close links to a sponsor and may include consulting contracts, part-time appointments, joint student supervision and knowledge transfer grants. Thursby et al. (2009) assume that such consulting contracts may hold a better explanation for industry owned academic patents.

This paper uses data from a 12-year panel of 492 engineering academics in the UK, and is able to measure industry interaction in terms of direct grants received from private firms. The data further allow us to differ between large research grants and small dissemination grants with industry. We are thus able to investigate whether there is a differential effect for large- and smallscale collaborations with industry.

The results show that UK researchers receiving funding from industry are more likely to produce patents, controlling for a variety of individual and departmental characteristics. Thus, as already argued by e.g. Bercovitz and Feldman (2008) or Owen-Smith and Powell (2001), the support of pro-commercialisation partners is key in steering researchers towards patenting. We find the effect of an industry partner to be strongest and most consistent in explaining the propensity to patent, indicating a pull or learning effect from industry. Partners from industry perhaps have a strong interest in pushing academics towards commercialisation to recover their research investments or are more likely to sponsor research for commercial application. However, the effect is even stronger for university owned patents indicating that industry involvement generally increases a researcher's preparedness to involve in patenting. Small grants have a positive effect on patenting regardless the source of the grant. These small grants, which may support dissemination activities, studentships and consulting are indicative of close links to sponsors and researchers' ability to source money for knowledge transfer and other research dissemination activities, including patenting. 
Lawson. Academic patenting: The importance of industry support.

Published in The Journal of Technology Transfer

The paper is organised as follows: Section 2 reviews existing literature, section 3 summarises the data and introduces the methodology, Section 4 presents the results and section 5, finally, concludes.

\section{Prior Literature}

Prior literature has shown that the support provided through the university is essential for successful patenting. Since the 1980s most universities in the US and across Europe have established commercialisation units (e.g. Technology Transfer Offices (TTOs)) to better identify commercial opportunities, provide expertise for efficient patenting and to source potential licensees of university inventions. Characteristics of these commercialisation units and the share of licensing revenue have indeed been found to positively influence the number of invention disclosures (e.g. Lach and Schankerman, 2008; Siegel et al., 2003; Thursby and Kemp, 2002; Thursby et al., 2009). Thus, activities of the university may increase the willingness of academic staff to patent and license, and encourage strategic choices in the dissemination of research (Geuna and Nesta, 2006; Thursby and Thursby, 2002). Although these findings suggest university policies and culture to have a strong impact on commercialisation activities, not all researchers are involved in patenting equally and there exists evidence for a skewed patenting process (Agrawal and Henderson, 2002; Azoulay et al., 2007; Thursby and Thursby, 2007). Individual factors appear to be far more important than institutional setting.

Research focussing on individual characteristics that may determine academics' patenting activities have mainly focussed on the relationship with publishing. It has repeatedly been argued that patents could potentially result from any applied research project that also generates publications. Agrawal and Henderson (2002), for instance, cite an engineering faculty member at MIT saying, "most patentable research is also publishable" (Agrawal and Henderson, 2002, p. 58). Indeed, both activities can be complementary, as the effort associated with both and the nature of research do not differ (Dasgupta and David, 1994). Hence, academics with the ability to conduct scientific research successfully also have the assets to produce commercial outputs. Accordingly, research by Zucker et al. (1998) suggests that researchers with an excellent publication record are also most likely to patent their research (see also Di Gregorio and Shane, 2003; Louis et al., 2001; Murray and Stern, 2007). Recent empirical work confirms the positive 
Lawson. Academic patenting: The importance of industry support.

Published in The Journal of Technology Transfer

impact of publication numbers on the propensity to patent (Calderini et al., 2007; Carayol, 2007; Fabrizio and DiMinin, 2008; Stephan et al., 2007). Studies by Breschi et al. (2005) on engineering academics in Italy, and Azoulay et al. (2007) on US scientists in life sciences, for example, report a positive correlation between the number of publications and patenting events. It therefore appears that academic research in terms of publications creates opportunities for commercial activities and that the two are closely linked.

None of these studies, however, addresses the relationship between research funding and patenting. Research funding, especially in applied engineering science, is essential to acquire laboratory equipment required for research and allows the employment of research assistants. Accordingly, surveys by Zucker et al. (1998) and Link et al. (2007) find that experience in managing grants leads to more effective patenting. Moreover, access to funding may support patenting directly through the provision of expertise by the funding agent or specific appropriation requirements of the grant. However, again, not all researchers receiving external grants pursue commercialisation of their research equally. While scientific experience and funding enable academics to produce and better recognise potentially patentable research, the academic may simply not ascribe high value to commercial activities. Traditionalists amongst academic researchers might indeed feel that commercialisation threatens academia and that the two should be distinct (Owen-Smith and Powell, 2001).

Building on this evidence, this paper investigates whether industry funding, rather than publications or external grants as such, are responsible for pushing researchers towards commercialisation. Several papers have shown that industry can provide funds and ideas for research (Lee, 2000; Mansfield, 1995; Siegel et al., 2003). Collaboration with industry and other applied sponsors may also help overcome the barrier between scientific and commercial activities. Contact with pro-commercialisation partners, whether this is an industry sponsor, an academic peer or a mentor, positively affects a researcher's attitude towards patenting as well as her ability to recognise commercial opportunities (Owen-Smith and Powell, 2001; Ozgen and Baron, 2007; Stuart and Ding, 2006). Indeed, Colyvas and Powell (2006), looking at technology transfer activities at Stanford University, observe that TTOs and researchers see industry sponsors as potential partners for patenting activities, i.e. licensing. Agrawal and Henderson (2002) cite a researcher at MIT as saying that industry steers their research towards patenting, thus 
Lawson. Academic patenting: The importance of industry support.

Published in The Journal of Technology Transfer

encouraging a commercial approach to science. Exchanges with the business community and joint research projects may hence help to overcome an intrinsic fear of change in academia and encourage academics to pursue patenting. One can therefore expect a positive effect of industry sponsorship on a researcher's propensity to patent.

A positive link between patenting and industry collaboration has already been confirmed in several survey studies. Gulbrandsen and Smeby (2005), in a survey of Norwegian academics, find a strong positive correlation between patenting and industry collaboration and funding. In a more recent study of UK researchers who have received EPSRC funding at least once, Crespi et al. (2011) also find that patenting academics are more likely to be involved in other types of knowledge transfer. Hottenrott and Thorwarth (2011) find a positive effect of industry sponsorship on patent citations for German science and engineering departments. Haeussler and Colyvas (2011) look at the existence of entrepreneurial family members and find that it correlates positive with patenting. Similarly, Dietz and Bozeman (2005) find that the number of years an academic has spent in industry has a positive effect on their patenting rate. All these studies are based on survey answers or cross-sections and there is little longitudinal evidence on the topic. Most longitudinal studies used industry co-authorship on academic papers as a measure for industry collaboration and found mixed evidence ranging from a positive effect on patenting to no or even a negative effect (Azoulay et al., 2007; Breschi et al., 2005; Carayol, 2007). Other papers look at industry (co-)ownership of university invented patents and find that industry owned academic patents are less basic and hold more immediate financial returns (Czarnitzki et al., 2011; Thursby et al., 2009). These papers, however, only consider projects that resulted in patents and do not help explain the determinants of patenting itself. There is therefore still a requirement for an analysis that measures the link between industry involvement and patenting.

\section{Data and Method}

To investigate the link between industry funds and patenting, we collected longitudinal data on academic, commercial and funding histories of 492 tenured engineering academics from ten UK universities for the period 1996 to 2007. Initially, researchers were identified using staff registers in academic calendars and on university websites, which provided the basis for collecting researchers' publication and patent histories from existing databases. Overall, information on 
Lawson. Academic patenting: The importance of industry support.

Published in The Journal of Technology Transfer

almost 4000 academics from 40 UK universities was collected (for a detailed description of the data see Banal-Estanol et al. 2010). Ten universities additionally provided information on external funding received from industry, government and public bodies for the period 1996 to 2007 (for a list of universities see Appendix A). The number of academics employed at these ten institutions between 1996 and 2007 is 1174 . Personal information could only be collected for 816 researchers. In the final analysis, the number is further reduced to 492, which represents those researchers that can be observed for the whole observation period. The data sources used and the variables are described below.

\subsection{Data collection and sample}

Data collection started with identifying all engineering departments in the UK and collecting staff records from university calendars and websites. Staff information, including full names and academic rank, could be recorded for engineering departments at 40 UK universities for a period of 22 years from 1986 to 2007. This was supplemented with publication and patent information. For each academic in the original dataset, patents stating her as an inventor on a European or World patent application were collected from the European Patent Office (EPO) database ${ }^{1}$. Only patents that were filed while she was working in one of the selected engineering departments were considered initially. Patents were collected if the academic was named as an inventor, hence, not only patents filed by the university but also those assigned to third parties, including industry, were recorded. Database construction required a manual search in the inventor database to identify those entries where the identity of the academic was certain. This was done by comparing addresses, titles and technology classes for all patents potentially attributable to each researcher. Information on academic articles published during the observation period was extracted from the ISI Science Citation Index (SCI) for each academic in the sample. Entries were matched using authors' names, affiliations and scientific fields.

As a second step, we approached the research offices of the 40 universities to gain information on external funding received by their engineering staff. Ten universities supplied detailed records

\footnotetext{
${ }^{1}$ Data were collected from the ESPACE ACCESS CD-Rom, a bibliographic information service on European and World patent applications.
} 
on private and public research grants held by their staff during the period 1996 to $2007^{2}$. This included names of principal investigators, funding periods, funding amounts and the natures of sponsoring agents. The information was matched with the existing database and resulted in a sample of 1174 researchers, which we supplemented with gender, $\mathrm{PhD}$ year and $\mathrm{PhD}$ subject information $^{3}$. Personal information was only available for 816 researchers and the sample was further reduced to those 492 researchers that can be observed for the whole 12-year period or at least until 2005. Appendix A reports the number of academics from each university in the original and the reduced sample. The sample composition stays largely the same with serious undersampling for only one university (University of Reading).

To address concerns over sample bias we compare the distribution of publication and patent numbers of researchers in the selected group of universities to those in other universities during the 12-year period. We perform Kolmogorov-Smirnov tests of the equality of distributions (displayed in Appendix B) and find that there is no significant difference between the patenting intensity of researchers in the selected group and those at other universities, but that they publish more papers in scientific journals. This difference in publication numbers is mainly driven by the University of Cambridge and if excluded, we no longer find a significant difference in publication distribution between the selected group and other universities. To account for this potential bias we will run regression including and excluding the University of Cambridge. Further, we analyse whether the distribution of the sample of 1174 researchers at selected universities and the subsample of 492 used in this analysis are equal. Again, the equality of distributions is analysed using Kolmogorov-Smirnov tests but we additionally use analysis of variance (ANOVA), which looks at mean differences while controlling by year and academic $\mathrm{rank}^{4}$. A significant difference in the distribution of publication numbers can be seen, however, once we control for seniority and year there are no significant mean differences between the original sample and the selected group. The distribution in the number of patents and the amount

\footnotetext{
${ }^{2} 6$ more universities sent records for a shorter period, 6 universities sent partial information, e.g. industry funding or researcher names were missing and 18 universities chose not to cooperate. For some of the 10 universities funding is available for earlier years, e.g. for 3 from 1990 onwards.

${ }^{3}$ Information was taken from personal websites or the Index to Theses, a listing of theses accepted for higher degrees in UK and Ireland.

${ }^{4}$ Patents, publications and funding differ significantly by calendar year and academic rank. Since we oversample on senior researchers due to the need for a long observation period, group differences may be correlated to differences in academic rank.
} 
and share of funding from industry also does not differ between the two groups. Hence, while there is a slight bias towards scientists with higher publication intensity in the selection of the ten universities, there is no significant difference in key measures between the group of researchers that can be observed for at least ten years and those that are only present for a shorter period, indicating that selection bias is unlikely to be a problem in this study as long as we control for seniority and calendar year.

For the subsample of 492 researchers, we additionally collected patents filed before the observation period and those filed with the UK Intellectual Property Office (UKIPO), available from the esp@cenet web interface. As each invention can lead to multiple patents, each entry was verified using the Derwent World Patents Index (DWPI) that contains information grouped around a base patent, thus enabling us to uniquely identify the original invention and avoid multiple counts. We collected all patents filed by each of the 492 researchers since 1978, and recorded the year of priority (which represents the date closest to invention), the patent applicant (which can be different from the inventor and is usually the university or a firm) and the status of the patent (applied or granted). Further, we consider patent quality by considering the number of forward citations to a patent in the first 5 years following its publication. The quality measure was taken from the EP-INV database produced by Kites, Bocconi University, and thus only includes citations to patents filed at the EPO. Patents prior to 1978 could not be considered due to changes in publication rules in the UK and the establishment of the EPO in the same year ${ }^{5}$. In total, 182 researchers (37\%) are inventors (at least one patent application between 1978 and 2007), and published 585 original patents. 166 patents were issued by the UKIPO, 349 were registered at the EPO and 70 at the WIPO that have not yet entered national or regional phase ${ }^{6}$. More than a third of patenting researchers (69 persons) filed only one patent during their entire career to date. $47 \%$ of patents are assigned to a company alone, $35 \%$ to universities and $5 \%$ jointly to universities and industry. The remaining $13 \%$ is owned by government or the inventors themselves. This confirms previous papers that showed that in Europe the majority of university

\footnotetext{
${ }^{5}$ The oldest granted UKIPO patent dates from 1964, indicating that patenting is not a new phenomenon in universities in the UK. However, before 1978 the UKIPO only published granted patents, those not granted were never published. Following the Patent Act in 1977, the UKIPO started to publish all patents filed under the act as patent applications. The EPO was established in 1977 and publishes all European patents as applications.

${ }^{6} \mathrm{~A}$ further 42 US patents were found but are not considered as the USPO only started publishing patent applications after February 2001. Before March 2001 only granted patents were published.
} 


\section{Lawson. Academic patenting: The importance of industry support.}

Published in The Journal of Technology Transfer

invented patents is not owned by the university but is assigned to industry or the inventors themselves (Geuna and Nesta, 2006; Lissoni et al., 2008).

The final dataset is a panel of 492 researchers from 1996 to 2007 containing patent, funding and publication data for each year as well as pre-sample information on patenting. Of the 182 academic inventors, 145 also filed patents during the observation period 1996 to 2007. The majority of researchers $(70.5 \%)$, however, does not patent during the observation period. Even amongst academics who patent during the 12 year period, 71 (49\%) do not file more than one patent. Hence, the average number of patents in our sample is very low with approximately 0.067 patents per academic per year and a share of zero observations of $94.25 \%$. This shows that patenting is not widely spread amongst university scientists even in applied engineering sciences. The average number of publications is 2.21 per academic per year, though we can observe large heterogeneity in publication numbers with the maximum number in one year being 30 articles for one academic. Researchers receive external funding from five different agents: (1) UK research councils, (2) industry, (3) government ministries (excluding research councils), (4) EU, and (5) not-for profit organisations. Academics receive more than half of their funding from the UK research councils, amounting to an average of 22,603 GBP per academic per year. An average of 8,892 GBP, $22 \%$ of funding, is received from industry sponsors. The other three funding agents contribute less than $10 \%$ each.

\subsection{Variables}

\subsubsection{Dependent variables}

Table 1 presents descriptions and summary statistics of dependent and independent variables. The dependent variables of interest is, firstly, whether a researcher filed at least one patent in a given year $\left(\right.$ dpat $\left._{i t}\right)$. We expect a positive effect of industry grants on patenting and patent rate.

It could further be assumed that links to industry may particularly favour patents assigned to industry. Firm-owned patents could be the results of consulting (Thursby et al., 2009) or joint research projects (Verspagen, 2006). We therefore expect industry sponsorship to increase specifically the propensity of filing an industry owned academic patents. Thus, in order to account for ownership of patents and under the assumption that industry sponsorship should 
Lawson. Academic patenting: The importance of industry support.

Published in The Journal of Technology Transfer

produce more industry owned patents, we also consider a dummy indpat ${ }_{i t}$ that takes the value 1 if a patent is owned by a private firm, and a dummy unipat ${ }_{i t}$ if a patent is owned by the university.

Further, industry partners provide expertise in patenting processes and may be better able to identify valuable inventions. Czarnitzki et al. (2011) and Thursby et al. (2009) look at university owned and industry owned academic patents and find that the latter represent less complex inventions that are more likely to produce immediate income to applicant firms. In a recent work, Lawson and Sterzi (2012) find that UK academic inventors who first file a patent while working in industry produce patents of higher quality, as measured in numbers of forward citations, than their purely academic peers, also after joining academia. We therefore also expect industry grants to be linked to more successful or higher quality inventions. To control for originality and quality of a patent and, again, assuming that industry sponsorship is more likely to produce more valuable patents, a dummy grant $_{i t}$ indicating granted patents and a dummy nongrant ${ }_{i t}$ are used. Further, we regress on the number of forward citations received in the first five years since application ( wcit $_{i t}$ ). Only citations before 2012 and to EPO patents are considered. For the quality measures ${\text { ( } \text { rant }_{i} \text {, nongrant }}_{i}$, fwcit ${ }_{i t}$ ) we only use patents filed before 2006 to allow for the necessary time from filing to grant and for citations.

\subsubsection{Main independent variables}

To estimate the effect of funding on patenting we include a measure of industry collaboration intensity as well as the amount of funding to account for the extent of external research income. To account for the length of a grant and to avoid focusing all the funding on the start of a project, the grant value was divided by the length of the grant period and equally distributed across years except for the first and last year of a project, which were assigned half-year values as they do not represent full years. We generate three-year moving averages of the grant (fund ${ }_{i t-1}$ ) to account for the length of the research projects and to allow for a lag in the effect of external income on commercial research activity of more than just one year. To estimate the impact of industry funding on patenting propensity we calculate the share of funding received from industry over the previous three years (indshare ${ }_{i t-1}$ ). On average, $25 \%$ of funding comes from industry with some researchers receiving funding exclusively from private sponsors. The correlation coefficients in table 2 show that the share of industry funding correlates stronger with patenting than with 


\section{Lawson. Academic patenting: The importance of industry support.}

Published in The Journal of Technology Transfer

publications though both coefficients are very small. Funding in general correlates stronger with publication numbers than with patenting.

However, not all industry grants may have the same purpose. Hottenrott and Lawson (2012) show that research motivated by small and medium-sized enterprises has a positive effect on patenting rates while large firms effect patenting negatively. The data used in this analysis include funding of different magnitudes that could be intended not only for research but also for travel, consulting, studentships or knowledge transfer. We differ between small and large grants, assuming that the latter is designed to support research and produce publications while the first may serve different adjacent activities, e.g. enable dissemination and knowledge transfer. Large grants are mainly provided by public agencies with few large grants coming from industry. Thursby et al. (2009) and Verspagen (2006) point at such joint research projects as a source of industry owned patents in a US and European context. Thus, the large sponsoring contracts with industry may indeed increase patenting opportunities for researchers. Small grants on the other hand are an indicator of close links to a sponsor, including consulting contracts, part-time appointments, joint student supervision or knowledge transfer grants. Thursby et al. (2009) suggest that such consulting contracts may hold a better explanation for industry owned academic patents. To investigate whether both explanations hold, we differ between research grants and small grants. The specific purpose of grants is not denoted in the data and hence the funding amount is used to infer the purpose of the grant. We define grants of $£ 50,000$ or more as research grants and grants of less than $£ 50,000$ as small purpose-driven grants ${ }^{7}$. Instead of the amount of funding received through either of the two types of grants, we consider the number of grants in either category (fundsmall it-1 $_{1}$ and fundres it-1 ), as well as the share of the number of grants coming

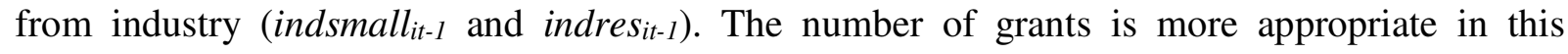
context as the value is already represented by the classification itself. Interestingly, industry sponsors more than $48 \%$ of small grants but just $19 \%$ of research grants. Most industry grants thus appear to be consulting income or match funding.

As patenting is expected to occur for very productive researchers, we also include the lagged number of publications $p u b_{i t-1}$ to the analysis. Table 2 shows that both measures are correlated

\footnotetext{
${ }^{7}$ Grant values were deflated and represent 2007 equivalent values. Results are very similar if only grants above $£ 100,000$ are considered research grants. Results also do not differ if amount is chosen instead of grant number.
} 
Lawson. Academic patenting: The importance of industry support.

Published in The Journal of Technology Transfer

but that funding correlates stronger with publication numbers than with patents. Most previous papers have found a positive link between publications and patents; however, few of these have included funding as additional explanatory variable. Hottenrott and Lawson (2012) and Hottenrott and Thorwarth (2011) considering both external grants and publications, find no significant effect of publications on patent numbers, but a positive effect of article citations on patent citations. Banal-Estanol et al. (2010) which uses the larger dataset of more than 4000 academics that also constitutes the basis of this analysis also finds no significant link between publications and patents.

\subsubsection{Research group measures}

Researchers are, of course, not only involved in projects in which they appear as a principal investigator but may benefit from funding available to other members of their research group as either co-investigators or through general benefits associated to increased research income of the group. We therefore create several variables that measure the amount and industry collaboration intensity of funding received by a researcher's co-authors. Thus, co-authoring researchers are assumed to share research grant benefits. We only take into account co-authors that a researcher has published shared work with in years $t, t-1$ and $t+1$. Three-year average funding variables are calculated for each co-author and then summed to measure the overall funding amount available to the group. In doing so, we take into account not only the selected 492 researchers but the full sample of 1174 researchers when calculating the co-author funding measures. Still, research groups defined this way are only calculated for researchers that publish in scientific journals and, as commercially oriented researchers may file patents rather than publish in papers (Owen-Smith and Powell, 2001), these variables may underestimate the effect of research group funding on academic patenting. In the sample, 76 researchers have no co-authors in their department during the entire sample period. Overall, for $47 \%$ of person-year observations we cannot assign any coauthors.

Additionally to industry, other peers and mentors may affect individual commercialisation behaviour. Bercovitz and Feldman (2008), analysing the disclosure activity of researchers at two medical schools in the US, find the patenting activity of researchers of similar rank in the same department to positively affect an academic's attitude towards patenting. This is confirmed by 
Lawson. Academic patenting: The importance of industry support.

Published in The Journal of Technology Transfer

Haeussler and Colyvas (2011) in a survey of UK and German life scientists that finds that peers' attitudes towards patenting correlate with a researcher's involvement in patenting. Several other papers also report evidence that the proportion of inventors at the university level and in the department has a positive effect on patenting (Breschi et al., 2005; Louis et al., 1989). This paper will also consider the patenting history of co-authors in its analysis, to control for local peer effects. We calculate the number of patents filed by a researcher's co-authors prior to observation period $t$ and exclude any co-invented patents, only measuring the additional patenting experience of co-authors or research group members. The numbers of patents invented by co-authors are summed, while avoiding any double counts through co-inventorship. 236 researchers in the sample have patenting co-authors. Again, we only consider research partners that have coauthored on academic papers and may thus underestimate the effect of research group patenting experience on the researcher's propensity to patent.

\subsubsection{Control variables}

In all regression we include variables for different academic ranks to control for differences in seniority. Academic rank information was collected from university calendars and denotes the four UK ranks: Lecturer, Senior Lecturer, Reader and Professor. Lecturer is the reference category in all regressions. We follow academics for at least 10 years and therefore observe their advancement from lecturer to professor. While in $199650 \%$ of researchers in the sample are lecturers and just $20 \%$ professors, this is reversed in 2007 and $46 \%$ of the sample have the rank of a professor while only $12 \%$ are still lecturers. Additionally to seniority in rank, we consider the number of years a researcher has spent in academia as the number of years since their $\mathrm{PhD}\left(\right.$ age $\left._{i t}\right)$. In 1996, the average number of years in academia is 14 years. Thus, assuming that an average researcher in the $\mathrm{UK}$ receives her $\mathrm{PhD}$ at the age of 28, the average age in 1996 was 42. Accordingly, in 2007 the average number of years in academia was 25 (age of 53 years). 38 researchers in the sample do not have a $\mathrm{PhD}$ degree and thus no age can be assigned. We include a dummy to control for this group and further include a variable for the 26 female researchers.

Though undoubtedly patenting is prompted primarily by an academic's desire to solve research questions (Levin and Stephan, 1991), it is also affected by the opportunities of the scientific field, the nature of rewards associated with patenting and the support given to the 
Lawson. Academic patenting: The importance of industry support.

Published in The Journal of Technology Transfer

academic (Dasgupta and David, 1994). The characteristics of the scientific field and industrial relevance of research are important factors in the opportunities for patenting research findings. Firstly, not all areas of research produce patentable outcomes, and other forms of commercial output and intellectual property, such as software and architectural works, may be generated. Secondly, the benefits associated with patenting differ between fields (Owen-Smith and Powell, 2001). It is therefore important to consider the scientific field in all regressions. Academics were grouped into engineering departments according to the subject of their $\mathrm{PhD}$. Four subject dummies were created, Bioscience, Chemistry \& Chemical Engineering (25\%), Physics and Electrical and Electronic Engineering (37\%), Mechanical Engineering (18\%) and Civil Engineering (20\%). Appendix C shows descriptive statistics for patents, publications and funding by field. These first statistics show that patenting is most widely spread in electrical and electronic engineering as well as chemical engineering. These two fields also show the largest average number of publications and citations, indicating a strong link between both types of research output. Academics in chemical engineering, however, receive least grants, indicating that it requires less financial resources than other engineering fields. There, thus, are significant differences between engineering disciplines, as shown by the ANOVA F statistics, and it is important to control by research field. University and year dummies are included in all regressions to control for university and year fixed effects.

\subsection{Methodology}

In order to control for unobserved heterogeneity and potential reverse causality we follow Blundell et al. (1995) and estimate a model using pre-sample values of the dependent variable as fixed effect proxies. We assume that unobserved heterogeneity in the data is mainly caused by the different knowledge stocks with which individuals enter the sample, and that patenting experience should contribute positively to a researcher's propensity to patent. The pre-sample value is given by the number of patents filed before 1996. In this sample, $80 \%$ of researchers have no patents filed before 1996. Theory further suggests that research activity and technological innovation are subject to dynamic feedback and it is therefore important to consider continuous, sample-period dynamics when modelling patent counts (Blundell et al., 1995). To proxy for patenting experience accumulated within the sample period we calculate the stock of patents filed during the observation period. Due to the short time window considered in this 


\section{Lawson. Academic patenting: The importance of industry support.}

Published in The Journal of Technology Transfer

analysis we do not consider that patenting knowledge depreciates during the observation period and therefore use the full count of patents. The sample period patenting stock is hence defined as the number of patents filed by an academic from 1996 to $t-1$.

Thus, to explore the relationship between industry funding and patenting, while considering unobserved heterogeneity, dynamic feedback, publication rate and other explanatory factors, we estimate the following equation: $\operatorname{Pr}\left(P_{\mathrm{it}}\right)=\beta_{0}+\beta_{1}$ Pstock $_{t, t-1}+\beta_{2}$ Pub $_{i, t-1}+\beta_{3}$ Fund $_{i, t-1}^{*}+\beta_{4}$ Ind $_{i, t-1}^{*}+\beta_{5}$ Peer $\tilde{r}_{t,-1}^{*}+\gamma_{1} x_{i t}+\gamma_{2} w_{i}+\eta_{i}+\tau_{t}+v_{i t}$

where $P_{i t}$ represents the dependent variable, thus whether a patent was filed or not or the number of citations. Pstock $k_{i t-1}$ measures a researcher's accumulated patenting stock from 1996 up to $t$ - 1 , $P u b_{i t-1}$ is the number of articles published in $t-1 ; F u n d_{i, t-1}^{*}$ represents the researcher's average tangible income or numbers of grants during the past three years and $I n d_{i, t-1}^{*}$ is the share of industry funding during the three years prior to $t$. Peer $_{i, t-1}^{*}$ are several variables indicating the patenting and funding activities of co-authoring researchers in the same department and $x_{i t}$ are other time variant variables, i.e. tenure and age. $w_{i}$ then represents other time invariant characteristics including scientific field and university fixed effects, $\eta_{i}$ is the individual specific fixed effect, measured as pre-sample patenting activity, $\tau_{t}$ is the time specific fixed effect and $v_{i t}$ the disturbance term.

\section{Results}

\subsection{Basic results}

We firstly estimate several logit models that estimate the propensity to file a patent in $t$. All standard errors are clustered at the individual level. Marginal effects are reported in table 3. Model (1) provides a baseline that includes the total amount of received funding and the share received from industry plus all controls and the publication measure. Looking at the controls first, we see that amongst the tenure variables only the professor category is positive and significant, suggesting that professors are more likely to file patents than lecturers, senior lecturers or readers. At the same time, the results show a negative age effect, suggesting that younger faculty is more likely to patent than their older peers, though the effect is very small. The dummy for researchers 
Lawson. Academic patenting: The importance of industry support.

Published in The Journal of Technology Transfer

that do not hold a $\mathrm{PhD}$ is significant and negative. The female dummy is negative but not significant. Researchers in mechanical and civil engineering are significantly less likely to file a patent than academics in chemical or electrical and electronic engineering. This confirms the descriptive statistics and shows that even in engineering there exists great heterogeneity concerning patenting opportunities.

Focussing on our variables of interest, we see that the amount of funding received in the previous three years does not predict patenting activity. Thus, research income does not necessarily increase the patenting activity of researchers. The share of funds from industry, however, is positive and significant. Figure 1 illustrates the predicted probabilities for different shares of industry sponsorship while holding all other regressors at their mean. As was already visible from table 3, industry sponsorship increases a researcher's propensity to patent, though the overall propensity remains small. Researchers with a higher share of funding from industry nonetheless are more likely to file a patent than researchers that receive little or no funding from industry. Publications, on the other hand, do not have a significant effect on patenting.

Model (2) adds co-author funding and model (3) also co-author patent histories. Funding received by co-authors has a weak positive effect that is only significant at $10 \%$ once we add coauthors' patent stock as an explanatory variable. The patenting experience of co-authors is found to be positive and significant. Thus, while publication numbers themselves do not explain patenting propensity, the funding and, even more so, the patent stock of co-authors on these publications have a positive significant effect. Other explanatory variables are not affected.

In models (4) and (5) we divide the funding variables into research grants and small grants for both the individual measures as well as the peer-group measures. The results from the baseline regression are confirmed in model (4). The share of industry funding for research grants has a positive and significant effect on patenting that is even stronger than in the baseline specification. The co-author funding measures are no longer significant. In model (5) we see quite a different result. While the number of small grants increases the propensity to patent, industry sponsorship is not relevant. Also small grants held by co-authors have a positive significant effect. This shows that grants do not act alike and that while the share of large-scale research sponsored by industry indeed predicts patenting, small grants up to an amount of $£ 50,000$ have a positive effect 
Lawson. Academic patenting: The importance of industry support.

Published in The Journal of Technology Transfer

regardless of the source of funding. These small grants may include industry consulting but also studentships or government grants for knowledge transfer and commercialisation. Thus, a large number of such purpose-driven grants, whether they come from industry or not and whether they are held by the researcher or her co-authors, may also be indicative of the researcher's patenting activity.

The fixed effect proxy, pre-sample patent control, is significant in all specifications and works in the expected direction. Also, the stock of patents is highly significant. The predicted probability to patent is increased by $10 \%$ if an academic has a patent stock of 10 patents while holding all other variables in the model at the mean.

Appendix B showed that the University of Cambridge may be responsible for a potential sample bias that favours the most research active academics. Therefore, in Appendix D, we report results from a regression that omits researchers from the University of Cambridge. The results are similar to those for the full sample. The amount of funding received in the last three years turns significant in models (1) to (3) while models (4) and (5) confirm that this effect is generated by small grants. Being a professor is no longer significant but female turns just significant. There are thus only minor differences to the main regression and the results may also hold if the study were extended to the full sample of 40 universities.

\subsection{Alternative patent measures}

Table 4 reports results for alternative patent measures and specifications. Model (1) presents the results of a bivariate probit model for industry owned and university owned patents. Different types of patents are estimated jointly as the patent regression explains both the number of industry owned and the number of university owned patents. The decisions in favour of one or the other (or in fact both) are interrelated and so are their error terms. This is confirmed by the likelihood ratio test. Co-author funding measures are not included in these regressions, but do not alter the results. The results show that there are some important differences between industry and university-owned patents. The share of research funding coming from industry is stronger correlated with the propensity to file a patent owned by the university. The effect is weaker and only significant at $10 \%$ for industry owned patents. Thus, unlike expectations expressed in section 2 , industry sponsorship does not only increase the propensity to file patents owned by 


\section{Lawson. Academic patenting: The importance of industry support.}

Published in The Journal of Technology Transfer

industry, but even more so the propensity to file patents owned by the university. The same is true for the number of small research grants. Thus, funding is a better predictor for university owned patents. The same is true for publications, which have a positive, though weakly significant, effect on university owned patents. Co-author patenting stock, on the other hand, only effects industry owned patents, increasing their probability. Also amongst the control variables, we can see some important differences between the two types of patents. Women are less likely to file patents with industry, but are not significantly different from men with regard to university owned patents. While chemical engineering and electrical and electronic engineering academics file more patents than civil and mechanical engineers in both categories, electric and electronic engineers are most likely to file patents with industry.

Model (2) estimates a bivariate probit model granted and non-granted patents for a reduced pre-2006 sample. Again, we can assume that the processes behind filing a patent are interrelated and independent from the later granting decision. This is confirmed by the LR test statistic. The results show that the intensity of industry research income is correlated with the probability of filing a patent that will later be granted. Small grants also have a stronger effect on successful patents. Purpose-driven grants and perhaps industry guidance may thus help to finance and guide the lengthy and expensive patenting process. The patenting history of co-authors equally affects the probability of filing any type of patent.

Models (3) and (4) report the results of left-censored tobit estimations for the number of forward citations and, for comparison, for the number of patent applications. Tobit estimators are chosen due to the large number of zero observations that require left censoring. Pre-sample and patent stock variables are based on the dependent variables; i.e. in model (3) they denote the number of citations to past patents. Further, we differ between two types of zero outcomes for the citation count: a) zero EPO patents, and b) zero citations, by adding 0.001 to each EPO patent and censoring at zero, i.e. censoring all observations with zero EPO patents. The results for the citation measure are similar to those of the count measure in model (4). Only the coefficient for the share of industry research funding is slightly larger for citations, indicating that industry sponsorship may have a positive impact on the quality of patents. 
Lawson. Academic patenting: The importance of industry support.

Published in The Journal of Technology Transfer

\subsection{Robustness check}

The results are verified using additional specifications in table 5 that estimate the patent hazard rate $h(t)$ of a researcher, the probability that a researcher will patent $t$ years after their last patent. We allow multiple patenting events for each researcher and, as we expect reoccurring patenting events to be highly correlated, we adopt a proportional hazard model that allows for unobserved heterogeneity (frailty model). Frailty models have previously been used in the analysis of patenting risk and patent citation hazards (e.g. Breschi et al., 2005; Marco, 2007) and given evidence for unobserved heterogeneity amongst researchers or patents. Shared frailty is also confirmed by the LR test statistic in the regressions reported here. One problem poses itself in the hazard model: we only observe a 12-year period and are unable to estimate the effect of industry collaboration on patenting before 1996. However, we know that $20 \%$ of researchers patented before 1996 and have been at risk of patenting again since their last patent. We therefore specify time $t$ as the number of years since the last patent, or since the year of $\mathrm{PhD}$ for researchers that have not filed any patents prior to $1996^{8}$, and specify the year 1996 as the year when a researcher came under observation. Table 5 presents the results of the frailty model, which confirm the results of the logit estimations in table 3. Researchers with a high share of industry funding in the three years prior to $t$ are more at risk of patenting, especially if this funding is supporting research. Researchers receiving a large number of small grants also increase the hazard rate of patenting. Publications are not found to have a significant impact on patenting after we include the funding activity of co-authors. Co-author's patenting stock is also positive but only significant at $10 \%$. The results also confirm the field effects with researchers in Chemical and Electrical and Electronic Engineering having a higher risk to patent than researchers in other fields of engineering.

\section{Conclusion}

The literature on knowledge transfer from universities to industry has largely focussed on university inventions and overlooked the importance of other collaboration channels in facilitating academic patenting. This study focuses on the effect that funding sourcing practices of researchers have on their propensity to patent. Based on a longitudinal sample of UK

\footnotetext{
${ }^{8}$ The earliest possible reference year is 1978 , which represents the first year we measure patent activity.
} 
Lawson. Academic patenting: The importance of industry support.

Published in The Journal of Technology Transfer

researchers we show that academics receiving funding from industry are more likely to produce patents, controlling for a variety of individual and departmental characteristics. We conclude that, as already argued by e.g. Bercovitz and Feldman (2008) or Owen-Smith and Powell (2001), the support of pro-commercialisation partners is key in steering researchers towards patenting. We find the effect of an industry partner to be strongest and most consistent in explaining the propensity to patent. This confirms results from survey studies (Crespi et al., 2011; Gulbrandsen and Smeby, 2005) and anecdotal evidence (Agrawal and Henderson, 2002; Colyvas and Powell, 2006), indicating a pull or learning effect from industry. Partners from industry perhaps have a strong interest in pushing academics towards commercialisation to recover their research investments or are more likely to sponsor research for commercial application. However, the effect is even stronger for university owned patents indicating that industry involvement generally increases a researcher's preparedness to involve in patenting. Small grants have a positive effect on patenting regardless the source of the grant. These small grants, which may support dissemination activities, studentships and consulting are indicative of close links to sponsors and ability to source money for knowledge transfer and other research dissemination activities, including patenting.

The findings inform universities of the need for joint research and technology transfer units. In the wake of the Bayh-Dole Act and similar policies in the UK and Europe universities set up dedicated Technology Transfer Offices in an effort to commercialise research. Often, these were separate from research offices that have traditionally provided administrative support for the acquisition of external funding. Our results indicate that the commercialisation efforts of universities cannot be isolated from other knowledge transfer activities. This is particularly the case for industry sponsorship and for acquiring small dissemination grants from a variety of sponsors. The results are further interesting to universities as they show that researchers receiving external grants will not necessarily hand rights to inventions to the external sponsor but are also more likely to file patents with the university.

Finally, with universities' budgets shrinking and industry sponsored research increasing as a share of funding in some countries the question of a shift in academic research is still important. While industry sponsorship encourages patenting activity at universities, this may come at the expense of basic research. Several papers have argued that industry sponsored research is more 
Lawson. Academic patenting: The importance of industry support.

Published in The Journal of Technology Transfer

applied and may decrease publication output (e.g. Hottenrott and Thorwarth, 2011; Banal-Estanol et al., 2010). Thus, while most papers currently find a positive or no effect of patenting on publications (e.g. Azoulay et al., 2009) this may change dramatically if more research is sponsored by industry. A policy that encourages a shift in research funding from public to private sponsorship will need to take this into account.

This paper has added some important evidence to the discussion on university-industry collaboration and its role in academic patenting, but has some limitations. The nature and purpose of grants could only be inferred and needs to be investigated in more detail to understand whether industry sponsors commercial research or whether it is more efficient in steering academics towards exploitation of research. Characteristics of sponsoring firm may be crucial in explaining either strategy as some firms may benefit from academic research more than others (e.g. Cohen et al., 2002). It is thus necessary to acquire more information on sponsors and projects to draw stronger conclusions.

\section{References}

Aghion, P., Dewatripont, M. Stein, J., 2008. Academic freedom, private-sector focus, and the process of innovation. The Rand Journal of Economics 39 (3), 617-635.

Agrawal, A., Henderson, R., 2002. Putting patents in context: exploring knowledge transfer from MIT. Management Science 48 (1), 44-60.

Azoulay, P., W. Ding, T. Stuart, 2007. The determinants of faculty patenting behavior: demographics or opportunities? Journal of Economic Behavior and Organization 63 (4), 599-623.

Azoulay, P., Ding, W. and Stuart, T., 2009. The Impact of Academic Patenting on the Rate, Quality and Direction of (Public) Research, The Journal of Industrial Economics 57, 637676.

Banal-Estanol, A., Jofre-Bonet, M., Meissner, C., 2010. The impact of industry collaboration on research: Evidence from engineering academics in the UK. UPF Working Paper no1190.

Bercovitz, J., Feldman, M., 2008. Academic entrepreneurs: organizational change at the individual level. Organization Science 19 (1), 69-89.

Blundell, R., Griffith, R., van Reenen, J., 1995. Dynamic count data models of technological innovation. Economic Journal 105 (429), 333-344.

Breschi S., Lissoni F., Montobbio F., 2005. From publishing to patenting: Do productive scientists turn into academic inventors? Revue d'Economie Industrielle 120 (1), 75-102.

Calderini, M., Franzoni, C., Vezzulli, A., 2007. If star scientists do not patent: The effect of productivity, basicness and impact on the decision to patent in the academic world. Research Policy 36 (3), 303-319. 
Lawson. Academic patenting: The importance of industry support.

Published in The Journal of Technology Transfer

Carayol, N., 2007. Academic incentives, research organization, and patenting at a large French university. Economics of Innovation and New Technology 16 (1-2), 119-138.

Colyvas, J.A., Powell, W.W., 2006. Roads to institutionalization: the remaking of boundaries between public and private science. Research in Organizational Behavior 27, 305-353.

Cohen, W.M., Nelson, R.R., Walsh J., 2002. Links and impacts: the influence of public research on industrial R\&D. Management Science 48, 1-23.

Crespi, G., D'Este, P., Fontana, R., Geuna, A., 2011. The Impact of Academic Patenting on University Research and its Transfer. Research Policy 40, 55-86.

Czarnitzki, D., Hussinger, K., Schneider, C., 2011. The nexus between science and industry: evidence from faculty inventions. Journal of Technology Transfer, forthcoming.

Dasgupta, P., David, P.A., 1994. Toward a new economics of science. Research Policy 23, 487521.

Dietz, J.S., Bozeman, B., 2005. Academic careers, patents, and productivity: industry experience as scientific and technical human capital. Research Policy 34, 349-367.

Di Gregorio, D., Shane, S., 2003. Why do some universities generate more start-ups than others? Research Policy 32, 209-227.

Fabrizio, K., DiMinin, A., 2008. Commercializing the Laboratory: Faculty Patenting and the Open Science Environment. Research Policy 37, 914-931.

Geuna, A., Nesta, L., 2006. University patenting and its effects on academic research: The emerging European evidence. Research Policy 35 (6), 790-807.

Gibbons, M., Johnston, R., 1975. The roles of science in technological innovation. Research Policy 3, 220-242

Gulbrandsen, M., Smeby, J-C., 2005. Industry funding and university professors' research performance. Research Policy 34 (6), 932-950.

Haeussler, C., Colyvas, J.A., 2011, Breaking the Ivory Tower: Academic entrepreneurship in the life sciences in UK and Germany Research Policy 40, 41-54.

Henderson, R.M., Jaffe, A.B., Trajtenberg, M., 1998. Universities as a source of commercial technology: a detailed analysis of university patenting 1965-1988. Review of Economics and Statistics 80 (1), 119-127.

Hottenrott, H., Thorwarth, S., 2011. Industry Funding of University Research and Scientific Productivity. Kyklos 64 (4), 534-555.

Hottenrott, H., Lawson, C., 2012. Research Grants, Sources of Ideas and the Effects on Academic Research. ZEW Discussion Paper 12-048, Mannheim.

Jensen, R., Thursby, M., 2001. Proofs and prototypes for sale: The licensing of university inventions. American Economic Review 91 (1), 240-259.

Lach, S., Schankerman, M., 2008. Incentives and invention in universities. The Rand Journal of Economics 39 (2), 403-433.

Lawson, C., Sterzi, V., 2012. The role of early career factors in academic patenting. LEI \& BRICK Working Paper 01/2012, Turin.

Lee, Y.S. 2000. The sustainability of university-industry research collaboration: an empirical assessment. Journal of Technology Transfer 25 (2), 111-133.

Levin, S., Stephan, P.E., 1991. Research productivity over the life cycle: Evidence for academic scientists. American Economic Review 81 (1), 114-132. 
Link, A.N., Siegel, D.S., Bozeman, B., 2007. An empirical analysis of the propensity of academics to engage in informal university technology transfer. Industrial and Corporate Change 16 (4), 641-655.

Lissoni, F., Llerena, P., McKelvey, M., Sanditov, B., 2008. Academic patenting in Europe: new evidence from the KEINS database. Research Evaluation, 17 (2), 87-102.

Louis, K.S., Blumenthal, D., Gluck, M.E., Stoto, M.A., 1989. Entrepreneurs in academe: An exploration of behaviors among life scientists. Administrative Science Quarterly 34, 110-131.

Louis, K.S., Jones, L.M., Anderson, M.S., Blumenthal, D., Campbell, E.G., 2001. Entrepreneurship, secrecy, and productivity: A comparison of clinical and non-clinical faculty. Journal of Technology Transfer 26 (3), 233-45.

Marco, A.C., 2007. The dynamics of patent citations. Economics Letters, 94 (2), 290-296.

Mansfield, E., 1995. Academic research underlying industrial innovations: Sources, characteristics, and financing. Review of Economics and Statistics 77 (1), 55-65.

Murray, F., Stern, S., 2007. Do formal intellectual property rights hinder the free flowof scientific knowledge? An empirical test of the anti-commons hypothesis. Journal of Economic Behavior \& Organization 63, 648-687.

Nelson, R.R., 1986. Institutions supporting technical advance in industry. American Economic Review Proceedings, 76, 186-189.

Owen-Smith, J., Powell, W.W., 2001a. To patent or not: Faculty Decisions and institutional success at technology transfer. Journal of Technology Transfer 26 (1/2), 99-114.

Ozgen, E. \& Baron, R. A., (2007). Social sources of information in opportunity recognition: effects of mentors, industry networks, and professional forums. Journal of Business Venturing, 22, 174-192.

Siegel, D.S., Waldman, D., Link, A., 2003. Assessing the impact of organizational practices on the relative productivity of university Technology Transfer Offices: An Exploratory Study. Research Policy 32, 27-48.

Siegel, D.S., Veugelers, R., Wright, M., 2007. Technology transfer offices and commercialization of university intellectual property: Performance and policy implications. Oxford Review of Economic Policy, 23(4), 640-660.

Stuart, T. E., Ding, W. W., 2006. When do scientists become entrepreneurs? The social structural antecedents of commercial activity in the academic life sciences. American Journal of Sociology, 112 (1), 97-144.

Stephan, P.E., Gurmu, S., Sumell, A.J., Black, G., 2007. Who's patenting in the university? Evidence from the survey of doctorate recipients. Economics of Innovation and New Technology 16 (2), 71-99.

Thursby, J., Fuller, A.W., Thursby, M., 2009. US faculty patenting: Inside and outside the university. Research Policy, 38, 14-25.

Thursby, J., Kemp, S., 2002. Growth and productive efficiency of university intellectual property licensing. Research Policy 31, 109-124.

Thursby, J., Thursby, M., 2002. Who is Selling the Ivory Tower: Sources of growth in university licensing. Management Science 48, 90-104.

Thursby, J., Thursby, M., 2007. Patterns of research and licensing activity of science and engineering faculty. In: Stephan, P., Ehrenberg, R. (eds.), Science and the University, University of Wisconsin Press, 77-93.

Verspagen, B., 2006. University research, intellectual property rights and European innovation systems. Journal of Economic Surveys, 20, 633-690. 
Lawson. Academic patenting: The importance of industry support.

Published in The Journal of Technology Transfer

Zucker, L.G., Darby, M.R., Brewer, M.B., 1998. Intellectual human capital and the birth of U. S. biotechnology enterprises. American Economic Review, 88, 290-336.

Table 1: Descriptive Statistics

\begin{tabular}{|c|c|c|c|c|c|c|}
\hline Regression Variables & Definition & Obs & Mean & SD & Min & Max \\
\hline \multicolumn{7}{|l|}{ Dependent Variable } \\
\hline dpat $_{\text {it }}$ & Dummy $=1$ if patents filed by individual $i$ in $t$ & 5320 & 0.053 & 0.224 & & \\
\hline indpat $_{\text {it }}$ & $\begin{array}{l}\text { Dummy }=1 \text { if patents by individual } i \text { in } t \text { owned } \\
\text { by industry }\end{array}$ & 5320 & 0.026 & 0.159 & & \\
\hline unipat $_{\text {it }}$ & $\begin{array}{l}\text { Dummy }=1 \text { if patents by individual } i \text { in } t \text { owned } \\
\text { by university }\end{array}$ & 5320 & 0.032 & 0.176 & & \\
\hline grantpat $_{\text {it }}$ & Dummy $=1$ if granted patents by individual $i$ in $t$ & 5320 & 0.026 & 0.158 & & \\
\hline nograntpat $_{\text {it }}$ & $\begin{array}{l}\text { Dummy }=1 \text { if filed but not granted patents by } \\
\text { individual } i \text { in } t\end{array}$ & 5320 & 0.030 & 0.171 & & \\
\hline pat $_{i t}$ & Number of filed patents by individual $i$ in $t$ & 5320 & 0.067 & 0.346 & 0 & 9 \\
\hline fwcit $_{\text {it }}$ & $\begin{array}{l}\text { Number of forward citations to patents filed by } \\
\text { individual } i \text { in } t\end{array}$ & 5320 & 0.032 & 0.368 & 0 & 9 \\
\hline \multicolumn{7}{|l|}{ Patentstock } \\
\hline prepat $_{\mathrm{i}}$ & Patents filed before 1996 & 5320 & 0.470 & 1.436 & 0 & 18 \\
\hline patstock $_{\mathrm{it}-1}$ & Patent stock from 1996 to t- 1 & 5320 & 0.375 & 1.239 & 0 & 19 \\
\hline prefwciti & Citations to patents filed before 1996 & 5320 & 0.375 & 1.860 & 0 & 22 \\
\hline fwcitstockit-1 & Patent citation stock from 1996 to t-1 & 5320 & 0.246 & 1.507 & 0 & 32 \\
\hline \multicolumn{7}{|l|}{ Funding } \\
\hline fund $_{\mathrm{it}-1}$ & $\begin{array}{l}\text { Average amount of funding received in previous } \\
3 \text { years (in } £ 10000 \text { ) }\end{array}$ & 5320 & 3.392 & 9.231 & 0 & 160.5 \\
\hline fundres $_{\mathrm{it}-1}$ & $\begin{array}{l}\text { Average number of grants }>=£ 50,000 \text { in } \\
\text { previous } 3 \text { years }\end{array}$ & 5320 & 0.915 & 1.687 & 0 & 18 \\
\hline fundsmall $_{\mathrm{it}-1}$ & $\begin{array}{l}\text { Average number of grants }<£ 50,000 \text { in previous } \\
3 \text { years }\end{array}$ & 5320 & 0.732 & 1.675 & 0 & 27 \\
\hline indshare $_{\mathrm{it}-1}$ & $\begin{array}{l}\text { Share of funding from industry over previous } 3 \\
\text { years }\end{array}$ & 5320 & $12.73 \%$ & $28.07 \%$ & $0 \%$ & $100 \%$ \\
\hline indres $_{\text {it- } 1}$ & $\begin{array}{l}\text { Share of industry grants }>=£ 50,000 \text { in previous } \\
3 \text { years }\end{array}$ & 5320 & $8.50 \%$ & $22.78 \%$ & $0 \%$ & $100 \%$ \\
\hline indsmall $_{\mathrm{it}-1}$ & $\begin{array}{l}\text { Share of industry grants }<£ 50,000 \text { in previous } 3 \\
\text { years }\end{array}$ & 5320 & $19.34 \%$ & $35.66 \%$ & $0 \%$ & $100 \%$ \\
\hline \multicolumn{7}{|c|}{ S } \\
\hline pub $_{\text {it-1 }}$ & Number of publications in $t-1$ & 5320 & 2.209 & 3.176 & 0 & 30 \\
\hline \multicolumn{7}{|l|}{ Research group } \\
\hline peerfund $_{\text {it-1 }}$ & $\begin{array}{l}\text { Average amount of funding of co-authors (in } \\
£ 10000 \text { ) }\end{array}$ & 5320 & 4.705 & 13.506 & 0 & 160.5 \\
\hline peerfundres $_{\text {it- } 1}$ & $\begin{array}{l}\text { Average number of co-authors' grants >= } \\
£ 50,000 \text { (prev. } 3 \text { years) }\end{array}$ & 5320 & 1.193 & 2.852 & 0 & 48 \\
\hline peerfundsmall $\mathrm{it}-1_{\mathrm{i}}$ & $\begin{array}{l}\text { Average number of co-authors' grants }<£ 50,000 \\
\text { (prev. } 3 \text { years) }\end{array}$ & 5320 & 0.947 & 2.817 & 0 & 53 \\
\hline peerindshare $_{\mathrm{it}-1}$ & $\begin{array}{l}\text { Share of co-authors' funding from industry (prev. } \\
3 \text { years) }\end{array}$ & 5320 & $7.70 \%$ & $20.35 \%$ & $0 \%$ & $100 \%$ \\
\hline peerindres $_{\mathrm{it}-1}$ & $\begin{array}{l}\text { Share of co-authors' industry grants }>=£ 50,000 \\
\text { (prev. } 3 \text { years) }\end{array}$ & 5320 & $5.87 \%$ & $17.31 \%$ & $0 \%$ & $100 \%$ \\
\hline peerindsmall $_{\mathrm{it}-1}$ & $\begin{array}{l}\text { Share of co-authors' industry grants }<£ 50,000 \\
\text { (prev. } 3 \text { years) }\end{array}$ & 5320 & $14.06 \%$ & $29.69 \%$ & $0 \%$ & $100 \%$ \\
\hline peerpat $_{\mathrm{it}-1}$ & Co-authors' patent stock up to $\mathrm{t}-1$ & 5320 & 0.407 & 1.445 & 0 & 23 \\
\hline \multicolumn{7}{|l|}{ Control variables } \\
\hline Lecturer $_{i t}$ & Dummy - reference category & 5320 & 0.248 & 0.432 & & \\
\hline Senior Lecturer ${ }_{\mathrm{it}}$ & Dummy & 5320 & 0.292 & 0.454 & & \\
\hline Reader $_{\text {it }}$ & Dummy & 5320 & 0.127 & 0.332 & & \\
\hline Professor $_{\text {it }}$ & Dummy & 5320 & 0.333 & 0.332 & & \\
\hline age $_{\text {it }}$ & Years since $\mathrm{PhD}$ & 4913 & 19.96 & 9.367 & 0 & 49 \\
\hline nophd $_{i}$ & Dummy & 5320 & 0.076 & 0.266 & & \\
\hline female $_{\mathrm{i}}$ & Dummy & 5320 & 0.053 & 0.224 & & \\
\hline Chemical Engineering $_{i}$ & Dummy - reference category & 5320 & 0.228 & 0.419 & & \\
\hline Mechanical Engineering $_{i}$ & Dummy & 5320 & 0.170 & 0.376 & & \\
\hline Electrical and Electronic $_{\mathrm{i}}$ & Dummy & 5320 & 0.341 & 0.474 & & \\
\hline Civil Engineering $_{i}$ & Dummy & 5320 & 0.184 & 0.388 & & \\
\hline
\end{tabular}


Lawson. Academic patenting: The importance of industry support.

Published in The Journal of Technology Transfer

Table 2: Correlation Matrix

\begin{tabular}{|c|c|c|c|c|c|c|c|}
\hline & dpat $_{\text {it }}$ & $\mathrm{pub}_{\mathrm{it}-1}$ & fund $_{i t-1}$ & indshare $_{\mathrm{it}-1}$ & fundres $_{\mathrm{it}-1}$ & indres $_{\mathrm{it}-1}$ & fundsmall $_{\mathrm{it}-1}$ \\
\hline pub $_{\text {it }-1}$ & $0.1072 *$ & & & & & & \\
\hline fund $_{\text {it-1 }}$ & $0.1139 *$ & $0.2417 *$ & & & & & \\
\hline indshare $_{\mathrm{it}-1}$ & $0.0628 *$ & 0.0190 & $0.1266 *$ & & & & \\
\hline fundres $_{i t-1}$ & $0.1335 *$ & $0.3318 *$ & $0.7549 *$ & $0.1871 *$ & & & \\
\hline indres $_{\mathrm{it}-1}$ & $0.0916 *$ & 0.0438 & $0.2083 *$ & $0.6819 *$ & $0.3195 *$ & & \\
\hline fundsmall $_{\text {it-1 }}$ & $0.0996 *$ & $0.1865 *$ & $0.3723 *$ & $0.2083 *$ & $0.4892 *$ & $0.1675 *$ & \\
\hline indsmall $_{\mathrm{it}-1}$ & $0.0640 *$ & $0.0755 *$ & $0.2339 *$ & $0.5663 *$ & $0.3280 *$ & $0.2802 *$ & $0.3777 *$ \\
\hline
\end{tabular}


Lawson. Academic patenting: The importance of industry support.

Published in The Journal of Technology Transfer

Table 3: Logistic regressions of patenting probability

\begin{tabular}{|c|c|c|c|c|c|}
\hline & $\begin{array}{l}\text { (1) } \\
\text { Margins }\end{array}$ & $\begin{array}{l}\text { (2) } \\
\text { Margins }\end{array}$ & $\begin{array}{l}\text { (3) } \\
\text { Margins }\end{array}$ & $\begin{array}{l}\text { (4) } \\
\text { Margins }\end{array}$ & $\begin{array}{l}\text { (5) } \\
\text { Margins }\end{array}$ \\
\hline \multicolumn{6}{|l|}{ Patentstock } \\
\hline prepat $_{\mathrm{i}}$ & $\begin{array}{l}0.005 * * \\
(0.002)\end{array}$ & $\begin{array}{l}0.005 * * * \\
(0.002)\end{array}$ & $\begin{array}{l}0.005 * * * \\
(0.002)\end{array}$ & $\begin{array}{l}0.005^{* *} \\
(0.002)\end{array}$ & $\begin{array}{l}0.004 * * \\
(0.002)\end{array}$ \\
\hline patstock $_{\mathrm{it}-1}$ & $\begin{array}{l}0.013 * * * \\
(0.003)\end{array}$ & $\begin{array}{l}0.013 * * * \\
(0.003)\end{array}$ & $\begin{array}{l}0.013 * * * \\
(0.003)\end{array}$ & $\begin{array}{l}0.012 * * * \\
(0.003)\end{array}$ & $\begin{array}{l}0.014 * * * \\
(0.003)\end{array}$ \\
\hline \multicolumn{6}{|l|}{ Funding } \\
\hline fund $_{\mathrm{it}-1}$ & $\begin{array}{l}0.001 \\
(0.000)\end{array}$ & $\begin{array}{l}0.000 \\
(0.000)\end{array}$ & $\begin{array}{l}0.000 \\
(0.000)\end{array}$ & & \\
\hline fundres $_{\mathrm{it}-1}$ & & & & $\begin{array}{l}0.004 * \\
(0.002)\end{array}$ & \\
\hline fundsmall $_{\mathrm{it}-1}$ & & & & & $\begin{array}{l}0.006 * * * \\
(0.002)\end{array}$ \\
\hline indshare $_{\mathrm{it}-1}$ & $\begin{array}{l}0.024 * * * \\
(0.008)\end{array}$ & $\begin{array}{l}0.023 * * * \\
(0.009)\end{array}$ & $\begin{array}{l}0.024 * * * \\
(0.001)\end{array}$ & & \\
\hline indres $_{\mathrm{it}-1}$ & & & & $\begin{array}{l}0.035 * * * \\
(0.010)\end{array}$ & \\
\hline indsmall $_{\mathrm{it}-1}$ & & & & & $\begin{array}{l}0.015 \\
(0.009)\end{array}$ \\
\hline \multicolumn{6}{|l|}{ Publications } \\
\hline $\mathrm{pub}_{\mathrm{it}-1}$ & $\begin{array}{l}0.002 \\
(0.001)\end{array}$ & $\begin{array}{l}0.001 \\
(0.000)\end{array}$ & $\begin{array}{l}0.001 \\
(0.001)\end{array}$ & $\begin{array}{l}0.000 \\
(0.001)\end{array}$ & $\begin{array}{l}0.000 \\
(0.001)\end{array}$ \\
\hline $\begin{array}{l}\text { Research group } \\
\text { peerpat }_{\text {it-1 }}\end{array}$ & & & $\begin{array}{l}0.003 * * \\
(0.001)\end{array}$ & $\begin{array}{l}0.003 * * * \\
(0.001)\end{array}$ & $\begin{array}{l}0.003 * * * \\
(0.001)\end{array}$ \\
\hline peerfund $_{\text {it-1 }}$ & & $\begin{array}{l}0.001 * * \\
(0.000)\end{array}$ & $\begin{array}{l}0.000^{*} \\
(0.000)\end{array}$ & & \\
\hline peerfundres $_{\mathrm{it}-1}$ & & & & $\begin{array}{l}0.001 \\
(0.001)\end{array}$ & \\
\hline peerfundsmall $_{\mathrm{it}-1}$ & & & & & $\begin{array}{l}0.003^{* *} \\
(0.001)\end{array}$ \\
\hline peerindshare $_{\mathrm{it}-1}$ & & $\begin{array}{l}0.006 \\
(0.015)\end{array}$ & $\begin{array}{l}0.005 \\
(0.015)\end{array}$ & & \\
\hline peerindres $_{\mathrm{it}-1}$ & & & & $\begin{array}{l}0.011 \\
(0.016)\end{array}$ & \\
\hline peerindsmall $\mathrm{it}_{\mathrm{t}-\mathrm{l}}$ & & & & & $\begin{array}{l}0.006 \\
(0.011)\end{array}$ \\
\hline \multicolumn{6}{|l|}{ Control variables } \\
\hline Lecturer $_{\text {it }}$ & reference category & & & & \\
\hline Senior Lecturer $_{\text {it }}$ & $\begin{array}{l}0.006 \\
(0.011)\end{array}$ & $\begin{array}{l}0.007 \\
(0.011)\end{array}$ & $\begin{array}{l}0.006 \\
(0.010)\end{array}$ & $\begin{array}{l}0.004 \\
(0.010)\end{array}$ & $\begin{array}{l}0.007 \\
(0.011)\end{array}$ \\
\hline Reader $_{\text {it }}$ & $\begin{array}{l}0.014 \\
(0.014)\end{array}$ & $\begin{array}{l}0.014 \\
(0.014)\end{array}$ & $\begin{array}{l}0.014 \\
(0.014)\end{array}$ & $\begin{array}{l}0.012 \\
(0.014)\end{array}$ & $\begin{array}{l}0.012 \\
(0.014)\end{array}$ \\
\hline Professor $_{i t}$ & $\begin{array}{l}0.026 * * \\
(0.013)\end{array}$ & $\begin{array}{l}0.026 * * \\
(0.013)\end{array}$ & $\begin{array}{l}0.025^{* *} \\
(0.013)\end{array}$ & $\begin{array}{l}0.019 \\
(0.012)\end{array}$ & $\begin{array}{l}0.021^{*} \\
(0.013)\end{array}$ \\
\hline $\mathrm{age}_{\mathrm{it}}$ & $\begin{array}{l}-0.002 * * * \\
(0.001)\end{array}$ & $\begin{array}{l}-0.002 * * * \\
(0.001)\end{array}$ & $\begin{array}{l}-0.002 * * * \\
(0.001)\end{array}$ & $\begin{array}{l}-0.001 * * * \\
(0.001)\end{array}$ & $\begin{array}{l}-0.001 * * * \\
(0.001)\end{array}$ \\
\hline nophd $_{i}$ & $\begin{array}{l}-0.160 * * * \\
(0.048)\end{array}$ & $\begin{array}{l}-0.159 * * * \\
(0.048)\end{array}$ & $\begin{array}{l}-0.157 * * * \\
(0.047)\end{array}$ & $\begin{array}{l}-0.155^{* * * *} \\
(0.047)\end{array}$ & $\begin{array}{l}-0.152 * * * \\
(0.047)\end{array}$ \\
\hline female $_{i}$ & $\begin{array}{l}-0.025 \\
(0.015)\end{array}$ & $\begin{array}{l}-0.024 \\
(0.016)\end{array}$ & $\begin{array}{l}-0.024 \\
(0.016)\end{array}$ & $\begin{array}{l}-0.023 \\
(0.015)\end{array}$ & $\begin{array}{l}-0.022 \\
(0.015)\end{array}$ \\
\hline Chemical Engineering $_{i}$ & reference category & & & & \\
\hline Mechanical Engineering $_{i}$ & $\begin{array}{l}-0.032 * * \\
(0.013)\end{array}$ & $\begin{array}{l}-0.034 * * * \\
(0.013)\end{array}$ & $\begin{array}{l}-0.034 * * \\
(0.013)\end{array}$ & $\begin{array}{l}-0.038^{* * * *} \\
(0.013)\end{array}$ & $\begin{array}{l}-0.037 * * * \\
(0.012)\end{array}$ \\
\hline Electrical and Electronic $c_{i}$ & $\begin{array}{l}0.009 \\
(0.009)\end{array}$ & $\begin{array}{l}0.007 \\
(0.008)\end{array}$ & $\begin{array}{l}0.008 \\
(0.008)\end{array}$ & $\begin{array}{l}0.006 \\
(0.008)\end{array}$ & $\begin{array}{l}0.008 \\
(0.008)\end{array}$ \\
\hline Civil Engineering $_{i}$ & $\begin{array}{l}-0.030 * * \\
(0.013)\end{array}$ & $\begin{array}{l}-0.029 * * \\
(0.013)\end{array}$ & $\begin{array}{l}-0.029 * * \\
(0.013)\end{array}$ & $\begin{array}{l}-0.031 * * \\
(0.013)\end{array}$ & $\begin{array}{l}-0.029 * * \\
(0.013)\end{array}$ \\
\hline Observations & 5,320 & 5,320 & 5,320 & 5,320 & 5,320 \\
\hline Log Likelihood & -934.1 & -930.1 & -927.8 & -923.0 & 918.0 \\
\hline Wald $\gamma^{2}$ & $219.59 * * *$ & $249.17 * * *$ & $244.77 * * *$ & $275.04 * * *$ & $265.41 * * *$ \\
\hline Ps-R ${ }^{2}$ (McFadden's) & 0.15 & 0.16 & 0.16 & 0.16 & 0.17 \\
\hline
\end{tabular}


Table 4: Regressions for alternative patenting measures

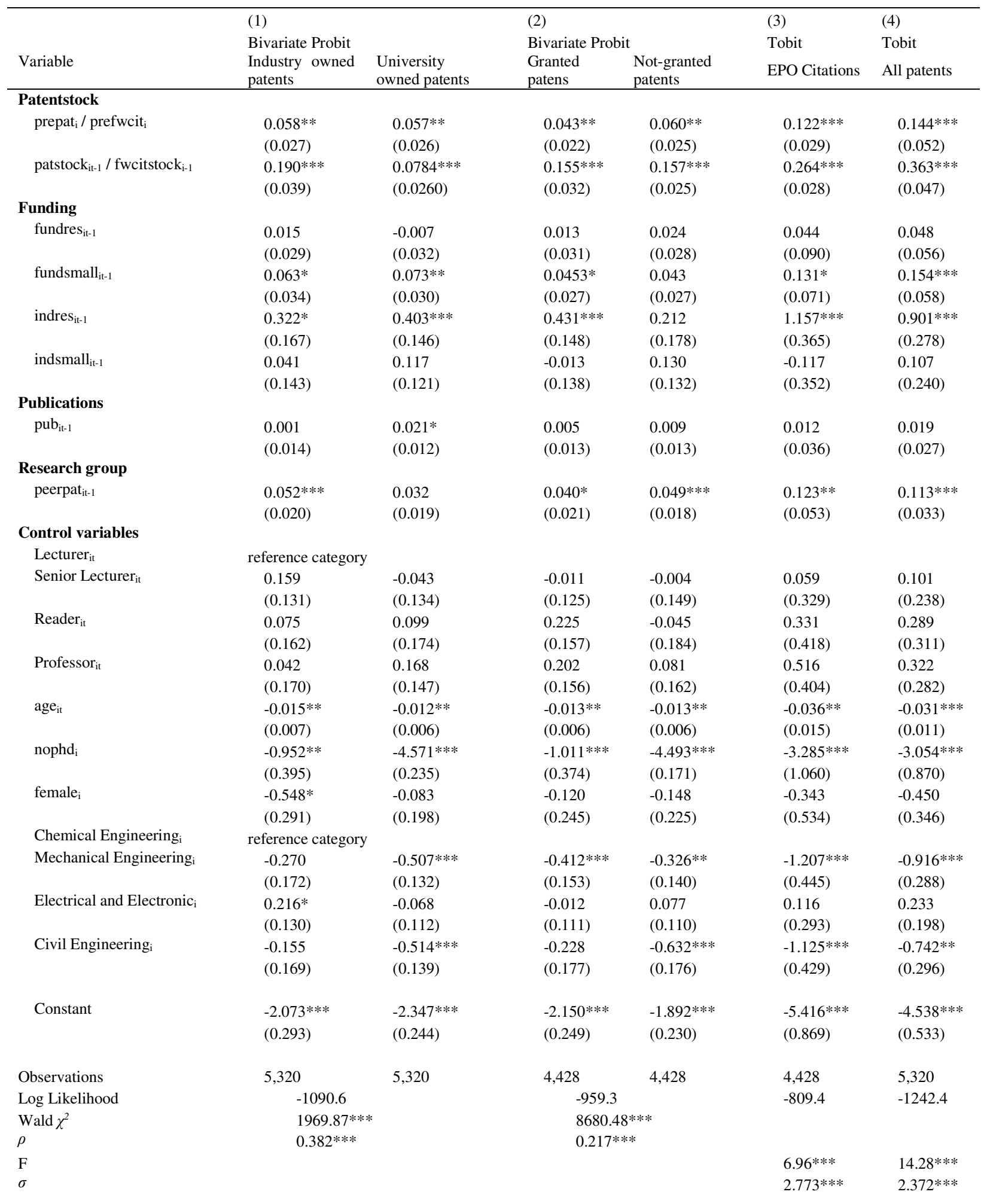


University and Year fixed effects included. Coefficients are reported.

Robust standard errors in parentheses. *** $\mathrm{p}<0.01$, ** $\mathrm{p}<0.05, * \mathrm{p}<0.1$

Table 5: Proportional hazard estimation (shared-frailty) of patenting.

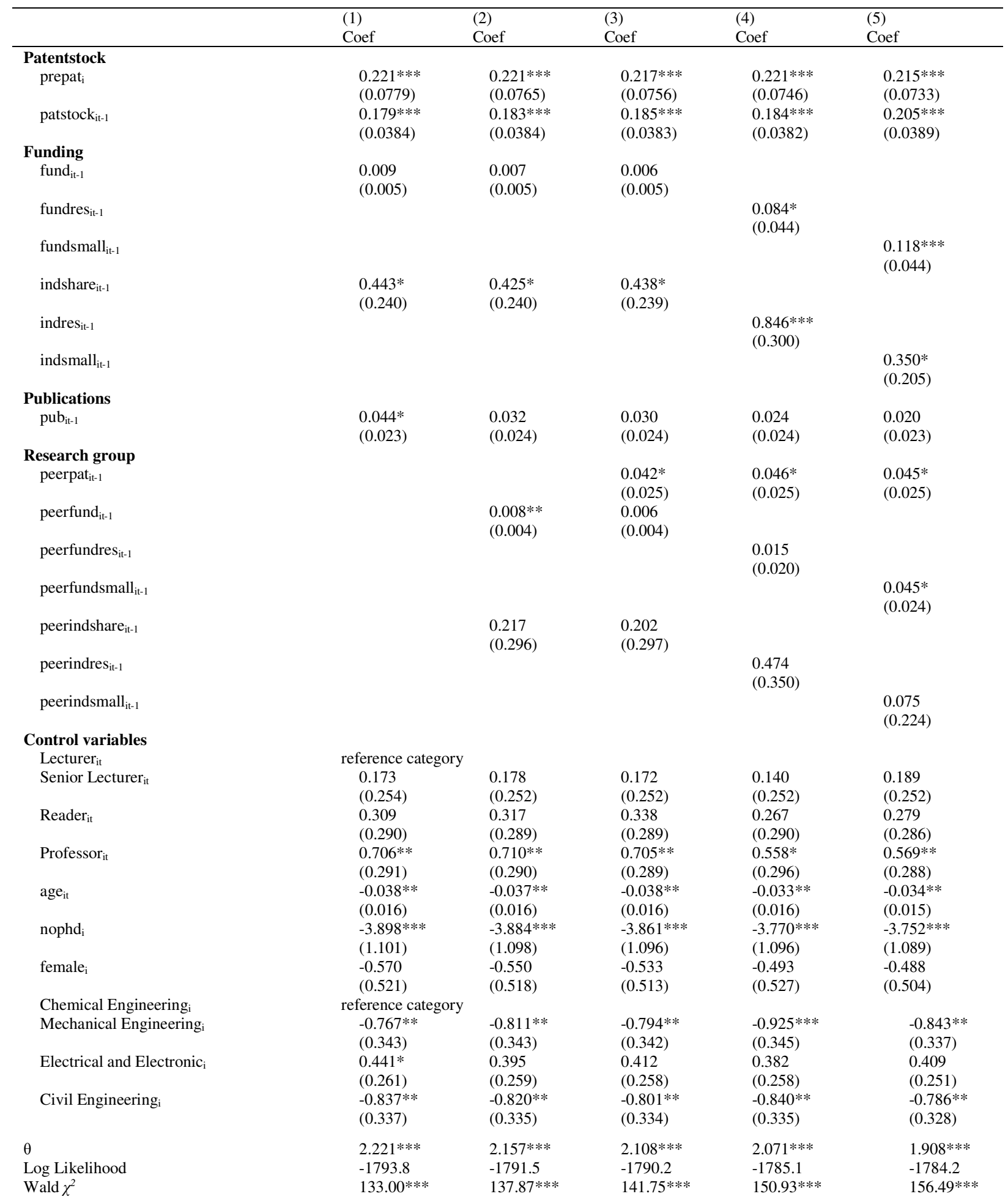


Lawson. Academic patenting: The importance of industry support.

Published in The Journal of Technology Transfer

\begin{tabular}{llllll} 
Observations & 5,320 & 5,320 & 5,320 & 5,320 & 5,320 \\
No of Failures & 282 & 282 & 282 & 282 & 282 \\
\hline
\end{tabular}

University and Year fixed effects included. Coefficients are reported.

Standard errors in parentheses. $* * * \mathrm{p}<0.01, * * \mathrm{p}<0.05, * \mathrm{p}<0.1$

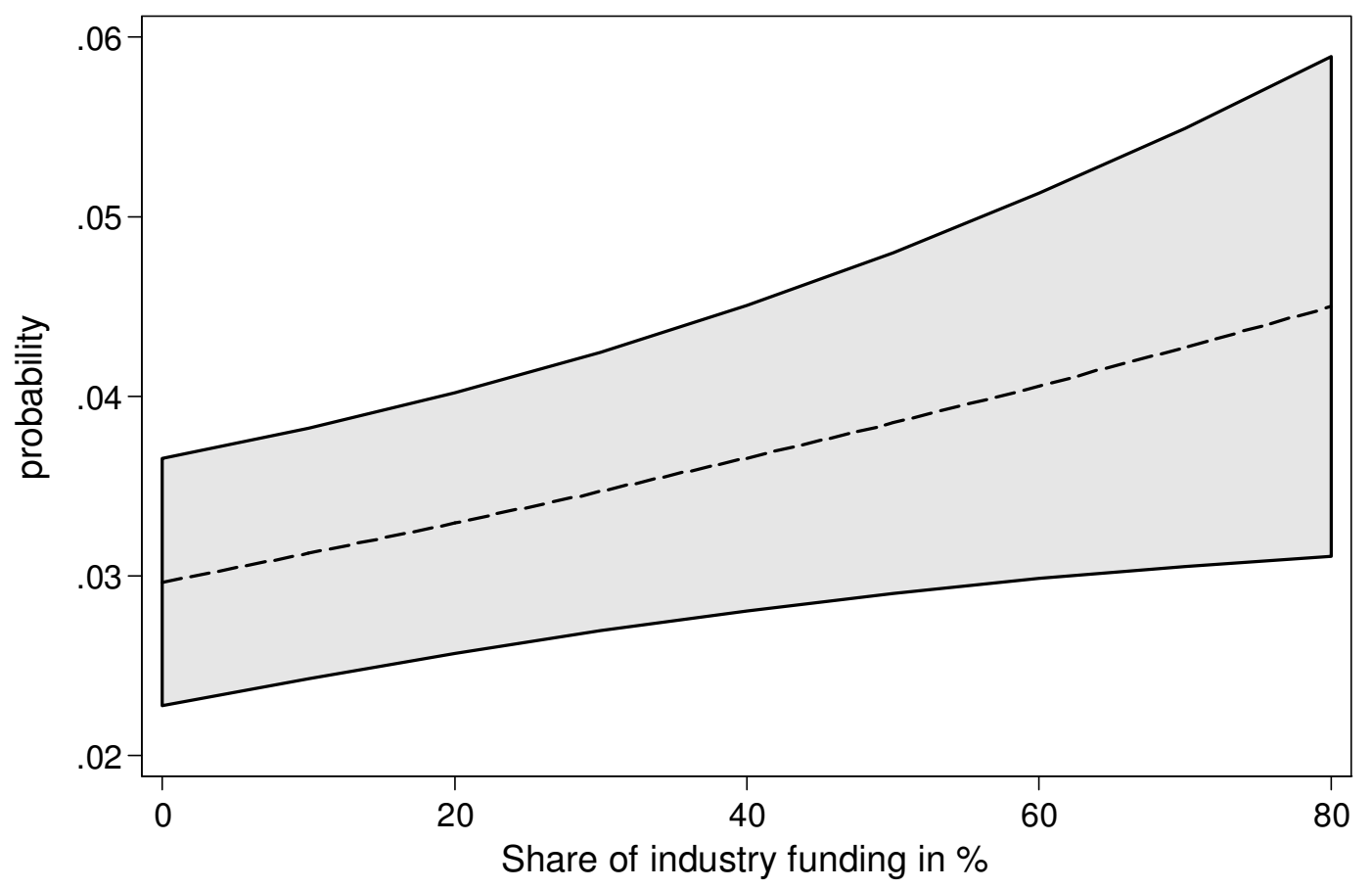

Fig. 1: Predicted patenting probabilities at means along with confidence interval 
Lawson. Academic patenting: The importance of industry support.

Published in The Journal of Technology Transfer

Appendix A: List of universities

\begin{tabular}{|c|c|c|c|c|}
\hline University Name & $\begin{array}{l}\text { Academics } \\
\# \text { and \% }\end{array}$ & Sample & $\begin{array}{l}\text { Academics in } \\
\# \text { and } \%\end{array}$ & Department \\
\hline University of Cambridge & 92 & $18.7 \%$ & 199 & $17.0 \%$ \\
\hline University of Durham & 13 & $2.6 \%$ & 43 & $3.7 \%$ \\
\hline University of Glasgow & 57 & $11.6 \%$ & 125 & $10.6 \%$ \\
\hline University of Lancaster & 9 & $1.8 \%$ & 31 & $2.6 \%$ \\
\hline University of Leicester & 22 & $4.5 \%$ & 34 & $2.9 \%$ \\
\hline Loughborough University & 99 & $20.1 \%$ & 251 & $21.4 \%$ \\
\hline University of Reading & 8 & $1.6 \%$ & 40 & $3.4 \%$ \\
\hline University of Sheffield & 82 & $16.7 \%$ & 164 & $14.0 \%$ \\
\hline University of Strathclyde & 72 & $14.6 \%$ & 203 & $17.3 \%$ \\
\hline University of Swansea & 38 & $7.7 \%$ & 84 & $7.2 \%$ \\
\hline Total & 492 & $100.0 \%$ & 1174 & $100.0 \%$ \\
\hline
\end{tabular}

Appendix B: Sample distribution differences

\begin{tabular}{l|cccc}
\hline & $\begin{array}{l}\text { Mean } \\
\text { Sample universities } \\
\text { n=1174 }\end{array}$ & $\begin{array}{l}\text { Mean } \\
\text { Other universities } \\
\mathbf{n = 3 2 1 4}\end{array}$ & $\begin{array}{l}\text { Diff. Distribution } \\
\text { Kolmogorov- } \\
\text { Smirnov test }\end{array}$ & $\begin{array}{l}\text { Anova } \\
\text { F }\end{array}$ \\
\hline Number of Patents (96-04) & $0.540(0.003)$ & $0.475(0.002)$ & 0.0030 & 3.26 \\
Number of Publications (96-07) & $2.045(0.030)$ & $1.753(0.016)$ & $0.0285 *$ & $76.23 *$ \\
\hline & $\begin{array}{l}\text { without Cambridge } \\
\mathbf{n = 9 7 5}\end{array}$ & $\begin{array}{l}\text { Other universities } \\
\mathbf{n = 3 2 1 4}\end{array}$ & $\begin{array}{l}\text { Diff. Distribution } \\
\text { K-S test }\end{array}$ & $\begin{array}{l}\text { Anova } \\
\text { F }\end{array}$ \\
\hline Number of Patents (96-04) & $0.429(0.003)$ & $0.475(0.002)$ & 0.0039 & 1.31 \\
Number of Publications (96-07) & $1.770(0.028)$ & $1.753(0.016)$ & 0.0061 & 0.01 \\
\hline & Final Sample & Rest & Diff. Distribution & Anova \\
\hline Number of Patents (96-04) & $\mathbf{n = 4 9 2}$ & $\mathbf{n = 6 8 2}$ & K-S test & F \\
\hline Number of Publications (96-07) & $0.059(0.005)$ & $0.052(0.005)$ & 0.0058 & 0.17 \\
Industry Funding Share (96-07) & $2.205(0.042)$ & $1.821(0.043)$ & $0.0869 *$ & 0.50 \\
Industry Funding (96-07) in £10000 & $0.288(0.016)$ & $0.261(0.024)$ & 0.0600 & 0.00 \\
\hline
\end{tabular}

ANOVA controlling for year and academic rank. Standard errors in parentheses. $* \mathrm{p}<0.001$

Appendix C: Means by engineering field

\begin{tabular}{lllll}
\hline & dpat $_{\text {it }}$ & pub $_{\text {it-1 }}$ & fund $_{\text {it-1 }}$ & indshare $_{\text {it-1 }}$ \\
\hline Chemical Engineering & $0.062(0.245)$ & $3.019(3.534)$ & $2.394(9.257)$ & $0.210(0.328)$ \\
Mechanical Engineering & $0.031(0.178)$ & $1.871(2.708)$ & $3.517(6.420)$ & $0.291(0.359)$ \\
Electrical and Electronic Engineering & $0.083(0.280)$ & $2.669(3.732)$ & $4.549(11.01)$ & $0.247(0.357)$ \\
Civil Engineering & $0.027(0.171)$ & $1.302(1.788)$ & $2.775(7.544)$ & $0.243(0.342)$ \\
\hline Number of Observations & 5320 & 5320 & 5320 & 2719 \\
Anova F & $\mathbf{1 6 . 0 5 *}$ & $\mathbf{5 1 . 9 3} *$ & $\mathbf{1 1 . 1 8} *$ & $\mathbf{3 . 3 1}$ \\
\hline
\end{tabular}

ANOVA controlling for year and academic rank. Standard deviations in parentheses. $* \mathrm{p}<0.001$ 
Lawson. Academic patenting: The importance of industry support.

Published in The Journal of Technology Transfer

Appendix D: Logistic regression of patenting probability (without Cambridge).

\begin{tabular}{|c|c|c|c|c|c|}
\hline & $\begin{array}{l}(1) \\
\text { Margins }\end{array}$ & $\begin{array}{l}(2) \\
\text { Margins }\end{array}$ & $\begin{array}{l}\text { (3) } \\
\text { Margins }\end{array}$ & $\begin{array}{l}(4) \\
\text { Margins }\end{array}$ & $\begin{array}{l}\text { (5) } \\
\text { Margins }\end{array}$ \\
\hline \multicolumn{6}{|l|}{ Patentstock } \\
\hline prepat $_{\mathrm{i}}$ & $\begin{array}{l}0.003 \\
(0.002)\end{array}$ & $\begin{array}{l}0.003 \\
(0.002)\end{array}$ & $\begin{array}{l}0.003 \\
(0.002)\end{array}$ & $\begin{array}{l}0.003 \\
(0.002)\end{array}$ & $\begin{array}{l}0.003 \\
(0.002)\end{array}$ \\
\hline patstock $_{\mathrm{it}-1}$ & $\begin{array}{l}0.014 * * * \\
(0.003)\end{array}$ & $\begin{array}{l}0.014 * * * \\
(0.003)\end{array}$ & $\begin{array}{l}0.014 * * * \\
(0.003)\end{array}$ & $\begin{array}{l}0.013 * * * \\
(0.003)\end{array}$ & $\begin{array}{l}0.015 * * * \\
(0.003)\end{array}$ \\
\hline \multicolumn{6}{|l|}{ Funding } \\
\hline fund $_{\text {it-1 }}$ & $\begin{array}{l}0.001 * * * \\
(0.000)\end{array}$ & $\begin{array}{l}0.001 * * * \\
(0.000)\end{array}$ & $\begin{array}{l}0.001 * * * \\
(0.000)\end{array}$ & & \\
\hline fundres $_{\text {it-1 }}$ & & & & $\begin{array}{l}0.004 \\
(0.003)\end{array}$ & \\
\hline fundsmall ${ }_{\text {it-1 }}$ & & & & & $\begin{array}{l}0.004 * * \\
(0.002)\end{array}$ \\
\hline indshare $_{\mathrm{it}-1}$ & $\begin{array}{l}0.020 * * \\
(0.009)\end{array}$ & $\begin{array}{l}0.022 * * \\
(0.009)\end{array}$ & $\begin{array}{l}0.023 * * \\
(0.009)\end{array}$ & & \\
\hline indres $_{\mathrm{it}-1}$ & & & & $\begin{array}{l}0.035 * * * \\
(0.011)\end{array}$ & \\
\hline indsmall $_{\mathrm{it}-1}$ & & & & & $\begin{array}{l}0.014 \\
(0.009)\end{array}$ \\
\hline \multicolumn{6}{|l|}{ Publications } \\
\hline pub $_{\text {it-1 }}$ & $\begin{array}{l}0.001 \\
(0.002)\end{array}$ & $\begin{array}{l}0.000 \\
(0.001)\end{array}$ & $\begin{array}{l}0.000 \\
(0.001)\end{array}$ & $\begin{array}{l}-0.000 \\
(0.001)\end{array}$ & $\begin{array}{l}0.000 \\
(0.001)\end{array}$ \\
\hline \multicolumn{6}{|l|}{ Research group } \\
\hline peerpat $_{\text {it-1 }}$ & & & $\begin{array}{l}0.004 * * * \\
(0.001)\end{array}$ & $\begin{array}{l}0.003^{* *} \\
(0.001)\end{array}$ & $\begin{array}{l}0.004 * * * \\
(0.002)\end{array}$ \\
\hline peerfund $_{i t-1}$ & & $\begin{array}{l}0.001 * * \\
(0.000)\end{array}$ & $\begin{array}{l}0.001 * * \\
(0.000)\end{array}$ & & \\
\hline peerfundres $_{\mathrm{it}-1}$ & & & & $\begin{array}{l}0.004 * * \\
(0.002)\end{array}$ & \\
\hline peerfundsmall $l_{\mathrm{it}-1}$ & & & & & $\begin{array}{l}0.002 * * \\
(0.001)\end{array}$ \\
\hline peerindshare $_{\mathrm{it}-1}$ & & $\begin{array}{l}0.010 \\
(0.015)\end{array}$ & $\begin{array}{l}0.010 \\
(0.015)\end{array}$ & & \\
\hline peerindres $_{\mathrm{it}-1}$ & & & & $\begin{array}{l}0.008 \\
(0.017)\end{array}$ & \\
\hline peerindsmall $_{\mathrm{it}-1}$ & & & & & $\begin{array}{l}0.007 \\
(0.011)\end{array}$ \\
\hline \multicolumn{6}{|l|}{ Control variables } \\
\hline Lecturer $_{\text {it }}$ & reference category & & & & \\
\hline Senior Lecturer $_{i t}$ & $\begin{array}{l}0.012 \\
(0.011)\end{array}$ & $\begin{array}{l}0.012 \\
(0.011)\end{array}$ & $\begin{array}{l}0.012 \\
(0.011)\end{array}$ & $\begin{array}{l}0.010 \\
(0.011)\end{array}$ & $\begin{array}{l}0.011 \\
(0.011)\end{array}$ \\
\hline Reader $_{\text {it }}$ & $\begin{array}{l}0.007 \\
(0.016)\end{array}$ & $\begin{array}{l}0.003 \\
(0.017)\end{array}$ & $\begin{array}{l}0.002 \\
(0.017)\end{array}$ & $\begin{array}{l}0.001 \\
(0.017)\end{array}$ & $\begin{array}{l}0.002 \\
(0.016)\end{array}$ \\
\hline Professor $_{\text {it }}$ & $\begin{array}{l}0.021 \\
(0.013)\end{array}$ & $\begin{array}{l}0.020 \\
(0.013)\end{array}$ & $\begin{array}{l}0.018 \\
(0.013)\end{array}$ & $\begin{array}{l}0.016 \\
(0.013)\end{array}$ & $\begin{array}{l}0.016 \\
(0.013)\end{array}$ \\
\hline age $_{\text {it }}$ & $\begin{array}{l}-0.001 * * \\
(0.001)\end{array}$ & $\begin{array}{l}-0.001 * * \\
(0.001)\end{array}$ & $\begin{array}{l}-0.001 * * \\
(0.001)\end{array}$ & $\begin{array}{l}-0.001 * \\
(0.001)\end{array}$ & $\begin{array}{l}-0.001 * * \\
(0.001)\end{array}$ \\
\hline nophd $_{i}$ & $\begin{array}{l}-0.121 * * * \\
(0.042)\end{array}$ & $\begin{array}{l}-0.117 * * * \\
(0.042)\end{array}$ & $\begin{array}{l}-0.115^{* * * *} \\
(0.041)\end{array}$ & $\begin{array}{l}-0.111 * * * \\
(0.041)\end{array}$ & $\begin{array}{l}-0.112 * * * \\
(0.042)\end{array}$ \\
\hline female $_{i}$ & $\begin{array}{l}-0.030 * \\
(0.017)\end{array}$ & $\begin{array}{l}-0.030 * \\
(0.017)\end{array}$ & $\begin{array}{l}-0.030^{*} \\
(0.017)\end{array}$ & $\begin{array}{l}-0.023 \\
(0.017)\end{array}$ & $\begin{array}{l}-0.030^{*} \\
(0.018)\end{array}$ \\
\hline Chemical Engineering ${ }_{i}$ & reference category & & & & \\
\hline Mechanical Engineering $g_{i}$ & $\begin{array}{l}-0.030 * * \\
(0.013)\end{array}$ & $\begin{array}{l}-0.031 * * \\
(0.013)\end{array}$ & $\begin{array}{l}-0.030 * * \\
(0.012)\end{array}$ & $\begin{array}{l}-0.033 * * * \\
(0.012)\end{array}$ & $\begin{array}{l}-0.030 * * \\
(0.012)\end{array}$ \\
\hline Electrical and Electronic $\mathrm{i}_{\mathrm{i}}$ & $\begin{array}{l}0.011 \\
(0.009)\end{array}$ & $\begin{array}{l}0.009 \\
(0.009)\end{array}$ & $\begin{array}{l}0.008 \\
(0.009)\end{array}$ & $\begin{array}{l}0.010 \\
(0.009)\end{array}$ & $\begin{array}{l}0.010 \\
(0.009)\end{array}$ \\
\hline Civil Engineering $_{i}$ & $\begin{array}{l}-0.033^{* *} \\
(0.014)\end{array}$ & $\begin{array}{l}-0.031 * * \\
(0.013)\end{array}$ & $\begin{array}{l}-0.031 * * \\
(0.013)\end{array}$ & $\begin{array}{l}-0.030 * * \\
(0.014)\end{array}$ & $\begin{array}{l}-0.027 * * \\
(0.013)\end{array}$ \\
\hline Observations & 4,332 & 4,332 & 4,332 & 4,332 & 4,332 \\
\hline Log Likelihood & -686.6 & -681.0 & -678.0 & -674.2 & -676.3 \\
\hline Wald $\chi^{2}$ & $219.88 * * *$ & $238.80 * * *$ & $295.80 * * *$ & $270.99 * * *$ & $311.48 * * *$ \\
\hline Ps-R ${ }^{2}$ (McFadden's) & 0.15 & 0.16 & 0.16 & 0.16 & 0.16 \\
\hline
\end{tabular}

University and Year fixed effects included. Marginal effects are reported.

Standard errors in parentheses. $* * * \mathrm{p}<0.01, * * \mathrm{p}<0.05, * \mathrm{p}<0.1$ 